\title{
Modeling and optimization of oxide copper cementation kinetics
}

\author{
Ebrahim Shahrivar $^{1} \cdot$ Mohammad Karamoozian $^{1}\left[\right.$ Mahdi Gharabaghi $^{2}$
}

Received: 16 December 2019 / Accepted: 12 February 2020 / Published online: 22 February 2020

(c) Springer Nature Switzerland AG 2020

\begin{abstract}
In this paper, the parameters affecting the process of copper cementation, its optimization and kinetic investigation are studied. For this purpose, the main parameters, such as $\mathrm{pH}$, copper concentrations, stirring speed, reaction time and the kinetics of the cementation process have been investigated by using the experimental design method. The results show that the three parameters of reaction time, stirring speed and copper concentrations, have the most effect on the copper cementation process, respectively. The experimental kinetic results showed that the reaction time and stirring speed have the most effect on the cementation kinetics, respectively. Also, the stirring speed -time interaction had the most effect on the cementation kinetics. Finally, the optimum conditions for cementation were $10 \mathrm{~min}$ time, copper concentration $3 \mathrm{~g} / \mathrm{l}, \mathrm{pH}=1$ and stirring speed of $500 \mathrm{RPM}$, that in the optimal conditions for cementation recovery was about $90 \%$ and the results showed that the recovery obtained from the experiments and the predicted recovery were in good agreement.
\end{abstract}

Keywords Cementation $\cdot$ Kinetics $\cdot$ Design of experiments $\cdot$ Optimization $\cdot$ Modeling

\section{Introduction}

Copper is used directly and indirectly in many industries because of its unique properties. The methods of copper extraction are pyrometallurgical and hydrometallurgical. Nowadays, Hydrometallurgical methods are often used for economic, environmental and energy reasons [1]. Copper ores are usually in the form of sulfide, oxide and native [2]. Malachite is a copper carbonate base mineral with the $\mathrm{Cu}_{2}(\mathrm{OH})_{2} \mathrm{CO}_{3}$ formula that contains $57.5 \%$ copper. It is known to be easily soluble in dilute acids, but there were few studies have conducted on the kinetics of dissolution process and the dependence of the rate on particle size, temperature, acid and chloride concentrations [3]. The most important techniques used to extract copper from oxide ores are hydrometallurgy and pyrometallurgy. Hydrometallurgy is mainly used to extract copper from oxide ore. In hydrometallurgy method, pollution and energy consumption are less than pyrometallurgy method. Sulfide ores are usually beneficiated using flotation methods, while copper oxide ores directly leached worldwide [4]. Studies on the leaching kinetics of copper sulfide ore indicate low kinetics while copper oxide ores have high leaching kinetics [5]. Copper metal is widely used in many industries, but the most important one is copper with a $55 \%$ consumption in the electronic and electrical industries. The use of copper and its alloys are considerable in the mechanical, pharmaceutical, mineralization, dyeing industries. Nowadays, with increasing exploitation of copper resources, as well as the expansion of industry, the need for this metal has increased and more valuable [6]. Due to the increasing global demand for copper, the development of environmentally compatible processes, including hydrometallurgical methods for the extraction of copper from low-grade ores, is taken into consideration [7]. Oxidized copper minerals such as malachite $\left(\mathrm{Cu}_{2}(\mathrm{OH})_{2} \mathrm{CO}_{3}\right)$, Azurite $\left(\mathrm{Cu}_{3}(\mathrm{OH}) \mathrm{CO}_{3}\right)_{2}$, Tenorite $(\mathrm{CuO})$ and Chrysocolle $\left(\mathrm{CuSiO}_{3} \cdot 2 \mathrm{H}_{2} \mathrm{O}\right)$, dissolve easily in acidic or

\footnotetext{
$\triangle$ Mohammad Karamoozian, m.karamoozian@shahroodut.ac.ir; Ebrahim Shahrivar, shahrivar.ebrahim@gmail.com; Mahdi Gharabaghi, gharabaghi@ut.ac.ir| ${ }^{1}$ Faculty of Mining, Petroleum and Geophysics Engineering, Shahrood University of Technology, Shahrood, Iran. ${ }^{2}$ Faculty of Mining Engineering, University of Tehran, Tehran, Iran.
} 
alkaline solutions [8]. Cementation is the oldest and most effective method for recovering thin solutions containing copper, which can be used to recover many metal cations in solution [9]. Low-grade oxide ores cannot be recovered using pyrometallurgical processes due to uneconomical reasons. Conventionally, stirred leaching and heap leaching methods have been used for low grade ores in the mineral industry. In these methods after leaching, the solution phase of the pregnancy to other processes such as solvent extraction (SX), electrowinning (EW) and cementation is transmitted to produce a copper cathode with a $99.99 \%$ grade of copper [10]. In recent years, by exploitation of copper resources, high grade mineral resources have been reduced. So the copper extraction from low grade sources has been considered. In 2002, the average copper ore grade was $1.13 \%$, while in 2011 , it was $0.84 \%$ [11]. Kinetics play a very important role in hydrometallurgical processes. In continuous systems the importance of this issue is growing. For a metal sediment to be fully resuspended, the cell potential must be greater than 0.3 volts and if it's less than that, metal precipitation will not be complete. Accordingly, It can be predicted that Iron (potential difference of cells with $0.777 \mathrm{~V}$ ), Aluminium (potential difference of cells with $2 \mathrm{~V}$ ) and Zinc (potential difference of cells with $1.1 \mathrm{~V}$ ) can be used for copper cementation. Among these metals, iron is the cheapest, so it is economical to be used in industry [12]. The substitution reaction of copper cementation with iron are as follows:

$\mathrm{Fe} \rightarrow \mathrm{Fe}^{2+}+2 \mathrm{e}^{-} \quad$ Anodic reaction

$\mathrm{Cu}^{2+}+2 \mathrm{e}^{-} \rightarrow \mathrm{Cu} \quad$ Cathodic reaction

$\mathrm{Cu}^{2+}+\mathrm{Fe} \rightarrow \mathrm{Fe}^{2+}+\mathrm{Cu}$ Overall reaction

Some other research has been done. Iraninejad et al. studied the kinetics of copper cementation. The influence of factors such as agitation speed, copper concentration, $\mathrm{pH}$, Fe level and reaction time were investigated on the kinetics of copper cementation from the solution, obtained from the leaching of on ore. Using the design of experiments (complete factorial) the results showed that among the main factors, agitation speed, $\mathrm{pH}$ and copper concentration and among the interactions, the interaction between copper concentration and $\mathrm{pH}$ had the most influence on the kinetics of copper cementation. The optimum conditions were $\mathrm{pH}$ of 1, stirring speed of 300 RPM, $k$ [13]. Yang Ku et al. performed a kinetics study of copper precipitation on iron by cementation reaction. They concluded that the kinetics order was first. Experimental equations were used to predict iron consumption by reducing hydrogen. It was also found that over-consumption of iron mainly reduces the hydrogen ions in the reaction, which is highly dependent on the $\mathrm{pH}$ of the reaction solution. The deposition rate of copper was obtained independently of the $\mathrm{pH}$ of the solution for acidic solutions. However, the formation of copper hydroxyl complexes may interfere with the deposition of copper at neutral and alkaline $\mathrm{pHs}$ [14]. Karostova investigated the kinetics and morphology of sediment deposition of copper on iron, zinc and aluminum. The kinetics of copper cementation on iron, zinc and aluminum powders were investigated at $60^{\circ} \mathrm{C}$ and $\mathrm{pH}=1$ together with the morphology of copper deposition. He resulted that copper cementation was increased with aluminum, iron and zinc. Increase it was also found that copper, zinc cementation was more effective than iron and aluminum cementation [15]. Demerican et al. investigated the kinetics study of copper-zinc metal cementation in aqueous solutions. They determined the effect of copper, zinc and ammonium chloride concentration, agitation speed, $\mathrm{pH}$ and temperature on copper cementation. Cementation rate increased with $\mathrm{Zn}^{2+}$ concentration. The cementation reaction kinetics followed the first order. It was observed that the reaction proceeded with a consecutive level of penetration control [16]. Gross et al. studied the cementation of copper in a mixture of iron and zinc using a rotating disk electrode. Iron and zinc were studied as precipitated metals. The results also confirm that zinc metal is the main factor of hydrogen evolution and thus reduces the corrosion of iron when the hydronium ion is reduced. Zinc protection experiments by galenic coupling were not completely successful as iron was still released in solution. As a result, this method was not successful for cementation [17].

The purpose of this study is to investigate the kinetics of copper cementation. For this purpose, the cement line of Dogan Copper Mine Processing Plant was selected as a case study. The factory cementing line operates continuously. In continuous hydrometallurgical lines, the dissolution kinetics is more important than discontinuous lines. For this purpose, determination of effective parameters on the cementation process, selection of optimal cementation conditions was done by designing experiments and kinetic evaluation of cementation process. A mathematical model for the relationship between the parameters affecting the cementation kinetics is not done in previous research that is investigated in this study.

\section{Materials and methods}

\subsection{Mineralogical studies}

Considering the importance of mineralogical characteristics such as ore structure and texture, type of constituent minerals, size and shape of minerals, copper grade, 
was considered in the first step Mineralogical studies were then performed on polished and thin sections for mineralogical, petrographic and degrees of freedom studies. To perform these studies, several sections in different size fractions $(+12,+35,+270$ and +400 mesh) were prepared from the representative sample. For example, Fig. 2, shows the cross section of the +12 mesh. Studies on the section indicated that the sample contains ferrous and copper minerals that were magnetite, hematite and malachite. X-ray diffraction analysis (XRD, D8-Advance, Bruker AXS Co.) was used for phase analysis on the representative sample. The XRD was operated at $35 \mathrm{kV}$ and $20 \mathrm{~mA}$ with a scanning rate of $3^{\circ} 2 \theta / \mathrm{min}$. Then X-ray fluorescence spectrometry (XRF) analysis was used to determine the amount of compounds present in the sample. XRF test was done by an automated Philips MagiX PRO wavelength-dispersive $X$-ray fluorescence spectrometer. XRF analysis showed $\mathrm{CuO}$ content of about $1.1 \%$, silica $\left(\mathrm{SiO}_{2}\right)$ content of $62.8 \%$ and $\mathrm{Al}_{2} \mathrm{O}_{3}$ content of about $15.1 \%$ (Table 1 ). The results indicated that a good amount of copper is present in the sample which can be used for leaching experiments. To identify the type of minerals in the sample, $\mathrm{X}$-ray diffraction spectroscopy (XRD) was performed on the representative sample. The results of XRD analysis are presented together with the mineralogical name, chemical formula and type of crystalline system of minerals in (Table 2). The mineralogical spectra obtained from XRD is shown in Fig. 1, that indicates the presence of copper-containing minerals in the sample (Fig. 2).

\subsection{Petrographic studies}

Petrography is used for structural studies and as a tool for observing rock layers. Petrographic microscopy (polarizing light-transmitting and reflecting microscopes with a maximum magnification of about 630 times, the German-made Litze model) was used to identify the mineral structure. To study the specimens, they first were prepared with a standard thickness of $30 \mu \mathrm{m}(0.03 \mathrm{~mm})$. The sample texture was studied under polarized light. The results of petrographic studies are summarized as follows; host rock: volcanic (andesitic) rocks, Initial components: crushed stone, alteration minerals: carbonate, quartz, clay minerals, cericite, iron oxides and non-metallic mineral: malachite. The main constituents of the rock were andesitic fragments. Figure 3 , shows some volcanic components impregnated with iron oxides.

\subsection{Degrees of freedom studies}

Studies on the degree of freedom of the sample were done on several sections. The sections were $+50,+120$ and +200 mesh. The freedom degrees of malachite at each cross section were $45.5,47$ and 67 , respectively.

\subsection{Basics of cementation method}

The deposition of one metal From its solution by another metal is called precipitation and this phenomenon is called in cementation industrial scale. In this process, a metal usually forms a coating on the surface of the precipitating
Table 1 XRF analysis of the prototype

Table 2 XRD analysis and compounds present in the sample

\begin{tabular}{lllllllllllll}
\hline Oxide & $\mathrm{Na}_{2} \mathrm{O}$ & $\mathrm{P}_{2} \mathrm{O}_{5}$ & $\mathrm{SO}_{3}$ & $\mathrm{TiO}_{2}$ & $\mathrm{~K}_{2} \mathrm{O}$ & $\mathrm{MgO}$ & $\mathrm{CaO}$ & $\mathrm{Fe}_{2} \mathrm{O}_{3}$ & $\mathrm{Al}_{2} \mathrm{O}_{3}$ & $\mathrm{SiO}_{2}$ & $\mathrm{CuO}$ & $\mathrm{LOI}$ \\
\hline Value (\%) & 2.47 & 0.13 & 0.014 & 0.4 & 1.4 & 1.09 & 2.14 & 4.1 & 15.1 & 62.8 & 1.1 & 9.256 \\
\hline
\end{tabular}

\begin{tabular}{lll}
\hline Compound Name & Formula & System \\
\hline Labradorite & $\left(\mathrm{Na}_{0.4} \mathrm{Ca}_{0.6}\right) \mathrm{Al}_{1} \cdot 6 \mathrm{Si}_{2} \cdot 4 \mathrm{O}_{8}$ & Triclinic \\
Quartz, syn & $\mathrm{SiO}_{2}$ & Hexagonal \\
Calcite, syn & $\mathrm{CaCO}_{3}$ & Hexagonal (Rh) \\
Albite, calcian & $(\mathrm{Na}, \mathrm{Ca}) \mathrm{Al}(\mathrm{Si}, \mathrm{Al})_{3} \mathrm{O}_{8}$ & Triclinic \\
Vermiculite & $(\mathrm{Mg}, \mathrm{Al})_{3}(\mathrm{Si}, \mathrm{Al})_{4} \mathrm{O}_{10}(\mathrm{OH})_{2} \cdot 4 \mathrm{H}_{2} \mathrm{O}$ & Monoclinic \\
Heulandite & $\mathrm{CaAl}_{2} \mathrm{Si}_{7} \mathrm{O}_{18} \cdot 7.5 \mathrm{H}_{2} \mathrm{O}$ & Monoclinic \\
Clinochlore & $\left(\mathrm{Mg}_{5} \mathrm{Al}\right)(\mathrm{Si}, \mathrm{Al})_{4} \mathrm{O}_{10}(\mathrm{OH})_{8}$ & Triclinic \\
Kaolinite-1 ITMd RG & $\mathrm{Al}_{2} \mathrm{Si}_{2} \mathrm{O}_{5}(\mathrm{OH})_{4}$ & Monoclinic \\
Malachite & $\mathrm{CuCO}_{3} \cdot \mathrm{Cu}(\mathrm{OH})_{2}$ & Monoclinic \\
Hematite, syn & $\mathrm{Fe}_{2} \mathrm{O}_{3}$ & Hexagonal (Rh) \\
Azurite & $2 \mathrm{CuCO} \cdot \mathrm{Cu}(\mathrm{OH})_{2}$ & \\
Goethite, syn & alpha-FeO$(\mathrm{OH})$ & Orthorhombic \\
Magnetite & $(\mathrm{Fe}, \mathrm{Mg})(\mathrm{Al}, \mathrm{Cr}, \mathrm{Fe}, \mathrm{Ti}) 2 \mathrm{O}_{4}$ & Cubic \\
\hline
\end{tabular}




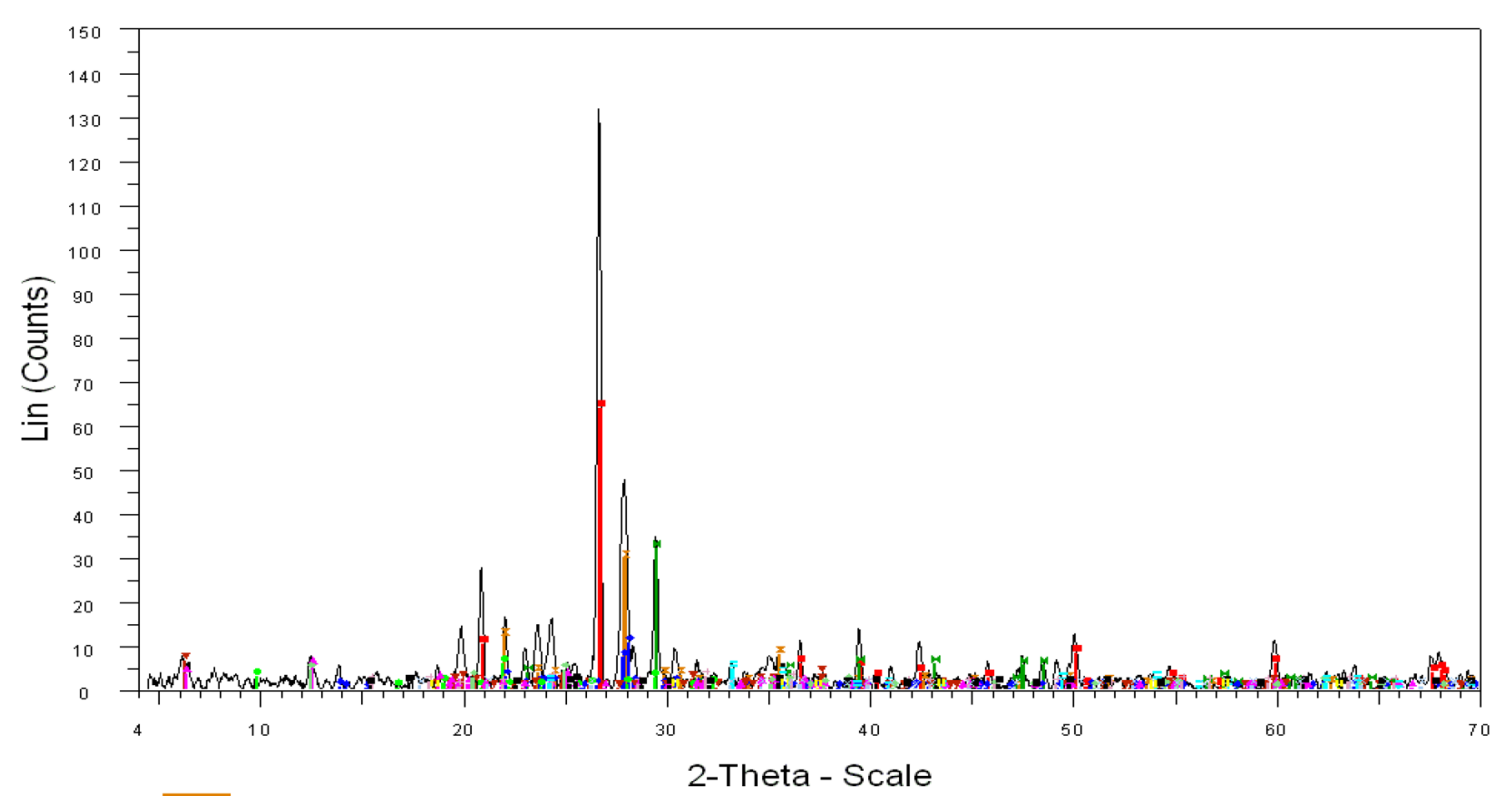

\begin{tabular}{|c|c|}
\hline II & Labradorit $27 / 7 \%$ \\
\hline & Ouartze $17 / 5 \%$ \\
\hline $5-4$ & Calcite $14 / 9 \%$ \\
\hline & t $4 / 3 \%$ \\
\hline$\sqrt{4}$ & Vermiculite 10 \\
\hline
\end{tabular}

Magnetite $0.5 \%$

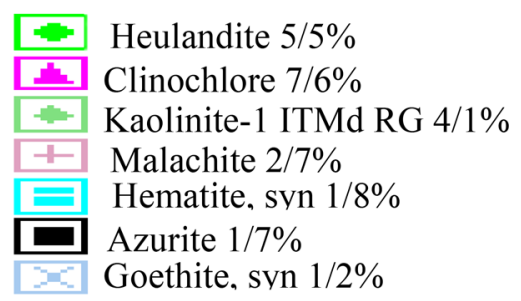

Kaolinite-1 ITMd RG 4/1\%

Malachite $2 / 7 \%$

Azurite 1/7\%

Goethite, syn 1/2\%

Fig. 1 X-ray diffraction spectrum (XRD) of the sample
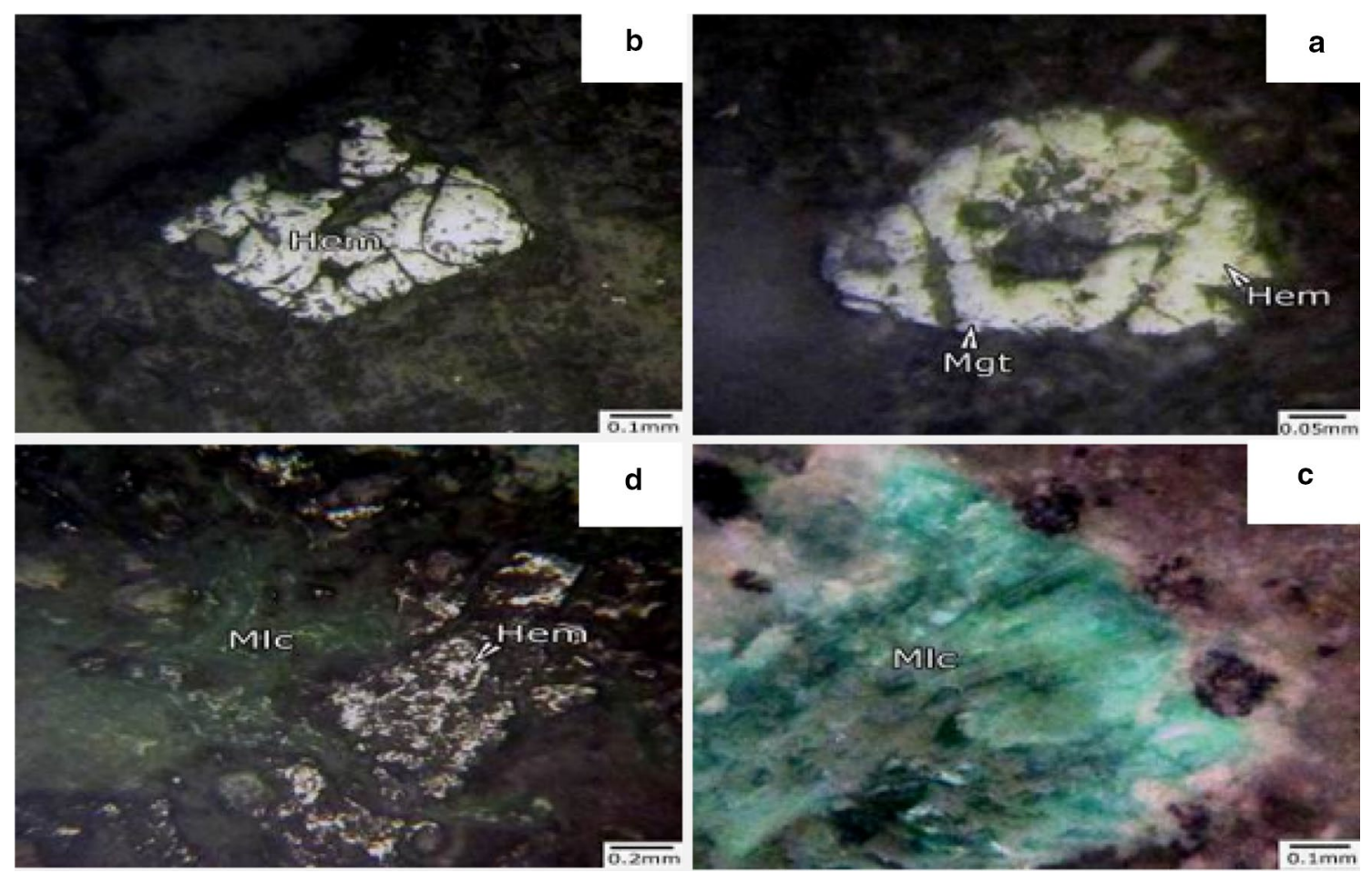

Fig. 2 a Hematite succession in magnetite crystals; b secondary hematite coarse crystals; c View of malachite minerals in XPL light as aggregates of elongated and filamentous crystals; $\mathbf{d}$ View of the crystals of hematite euhedral in the field of malachite

\section{SN Applied Sciences}



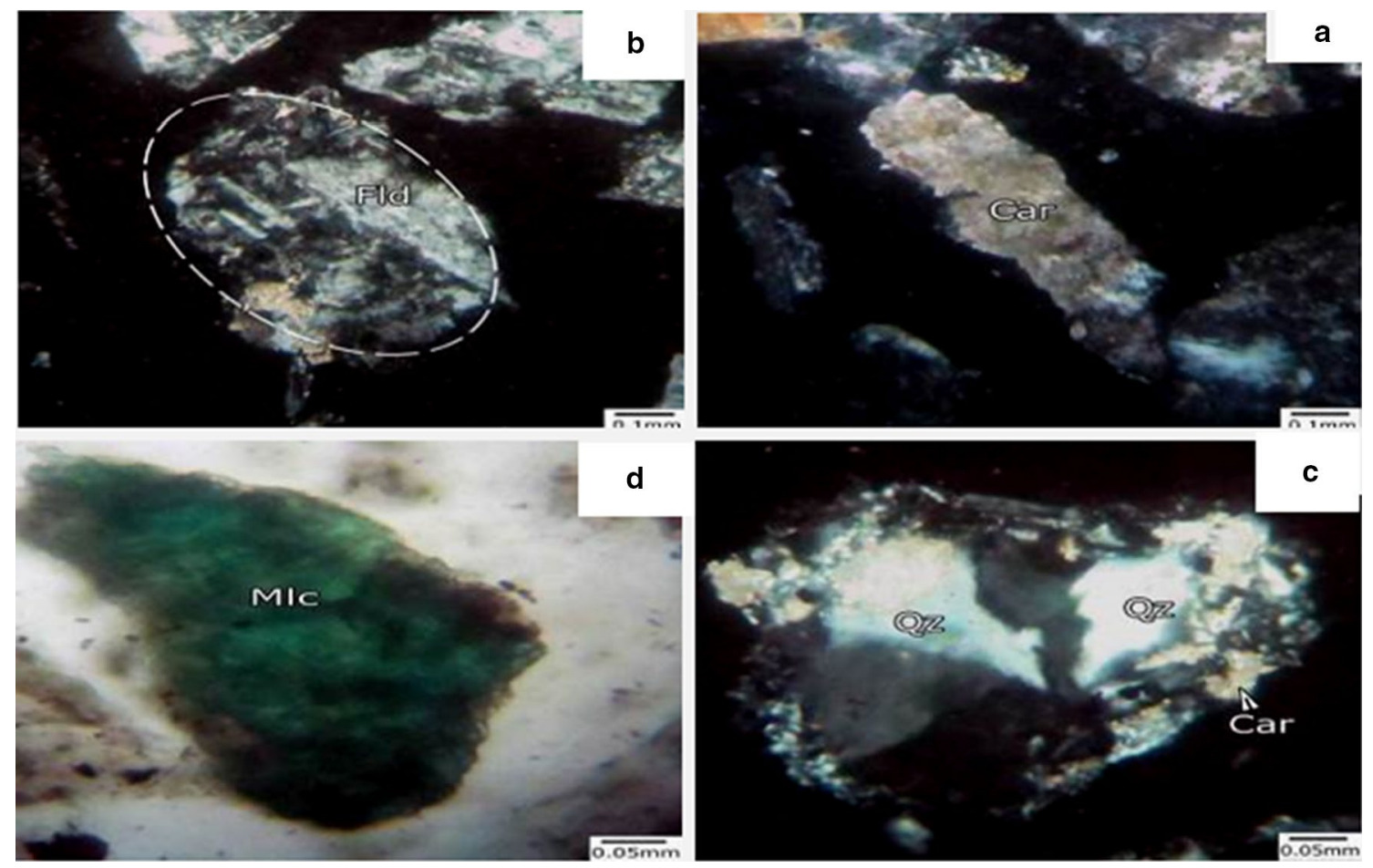

Fig. 3 a carbonization of volcanic rocks; b Fenocryst and microlithic crystals of feldspar forming volcanic rocks; c severe carbonate and quartz succession in volcanic rocks; d PPL light Malachite crystal indicator with green indicator color

metal and therefore simulates the substitution reaction to cementation. In metal processing processes, deposition of a metal can be predicted by its electrical potential. The electrical potential of metals depends on the concentration of the metal ion and the hydrogen ion. The electrical potential of a metal with its ion concentration in solution is as follows:

$E_{M+}=E_{+}^{0}+\frac{0.059}{Z} \log \left[M^{+}\right]$

Regarding the above equation, it is clear that the electrical potential of a metal decreases as the concentration of its ions decreases. $Z$ is the number of electrons that react in the electrocution current. In this formula $E_{M_{+}}$is the potential of the standard metal electrode obtained from Table 3. According to the electrochemical law, a metal with a lower reduction potential can release and adsorb a metal with a higher reduction potential (more positive electrical potential) than its soluble salt. This is an electrochemical reaction that is redacted, resuspended in the metal cathode and oxidized on the anode. The potential difference of cell $\left(E_{\text {cell }}^{o}\right)$ is calculated from the following equation:

$E_{\text {cell }}^{o}=E_{c}^{o}-E_{A}^{o}$

$E_{A}^{O}$ is the standard electrical potential of anode (metal with low electric potential), $E_{c}^{O}$ is the cathode electrical potential (metal with high electric potential). In order to complete
Table 3 Electrochemical potential of some elements

\begin{tabular}{ll}
\hline Element & Volt \\
\hline $\mathrm{Al} . \mathrm{Al}^{3+}$ & +1.66 \\
$\mathrm{Zn} . \mathrm{Zn}^{2+}$ & +0.763 \\
$\mathrm{Fe}_{\mathrm{Fe}}{ }^{2+}$ & +0.44 \\
$\mathrm{Ni} . \mathrm{Ni}^{2+}$ & +0.25 \\
$\mathrm{~Pb} . \mathrm{Pb}^{2+}$ & +0.126 \\
$\mathrm{Fe}^{2+} \mathrm{Fe}^{3+}$ & +0.036 \\
$\mathrm{Cu} . \mathrm{Cu}^{2+}$ & -0.337 \\
$\mathrm{Cu} . \mathrm{Cu}^{+}$ & -0.52 \\
\hline
\end{tabular}

the precipitation, the potential difference of the cell must be greater than $0.3 \mathrm{~V}$, and if it is lower than this, the metal will not precipitate. Among these metals, iron is the cheapest of all, so it is economical to be used in industry.

\section{Materials}

The case study is located $100 \mathrm{~km}$ south of Shahrood and $170 \mathrm{~km}$ southeast of Damghan and $10 \mathrm{~km}$ northwest of Taroud village. For the experiments, a sample of $200 \mathrm{~kg}$ with a grade of $1.1 \%$ was provided under standard conditions from the vibration mill product of the plant. For the cementation tests, a leaching test was initially performed at the high acid concentration 
(200 kg/ton) and long time (210 min) and a solid percent of $55 \%$ to produce the origin solution at the appropriate concentration for the cementation tests. The solution obtained from this experiment had $7.3 \mathrm{~g} / \mathrm{l}$ copper and $0.41 \mathrm{~g} / \mathrm{l}$ iron at $\mathrm{pH}=0.9$ and was considered as high level in the experiments. Another solution sample was obtained from leaching experiments using PLS solution containing $3 \mathrm{~g} / \mathrm{l}$ of copper, which was used as low level of tests. PLS (Pregnant Leach Solution) of leaching test as well as PLS origin solution were used for cementation experiments. Therefore PLS solution was prepared first. For the purpose of performing cementation iron pieces were used, All cementation experiments were performed in a volume of $300 \mathrm{ml}$. The hot plate device was used to adjust the stirring speed and time of reaction. All experiments were performed in the ambient temperature. First $300 \mathrm{ml}$ of PLS was poured into the beaker and the iron was placed in PLS solution and cemented with each stirring cycle of each experiment. Considering the test time, then a vacuum filter was used to separate the liquid phase from the solid, after complete filtration, the solution was analyzed by atomic absorbtion. It is necessary to mention from Ammonia (soluble) was used to increase $\mathrm{pH}$. In the following, the effect of the parameters were investigated by design of experiments and the kinetics of cementation was also investigated. In the industry, scrap iron is used for copper cementation due to economic issues. But for cementing tests, you have to use iron parts with a certain surface should be used, because the available iron surface is one of the factors affecting the cementation kinetics. In this reserch study of iron plates with dimensions of $2 \times 3 \mathrm{~cm}$ were used. A scheme of the reactor is presented in Fig. 4.

\section{Results and discussion}

Criteria for measuring the efficiency of cementation, are usually copper recovery, iron consumption and reaction kinetics. The cementation kinetics has an effect on the volume of the reactor and therefore on the investment costs. The high kinetics reduces the reactor volume and thus reduces the initial investment volume. It should be noted that one of the causes of excess iron consumption (greater than stoichiometry) is the dissolution of iron by acid, which is directly related to the residence time in the reactor. Therefore, increasing the kinetics will reduce the retention time, thereby reducing iron consumption and consequently reducing operating costs. The kinetics in a discontinuous reactor is calculated from the following equation:

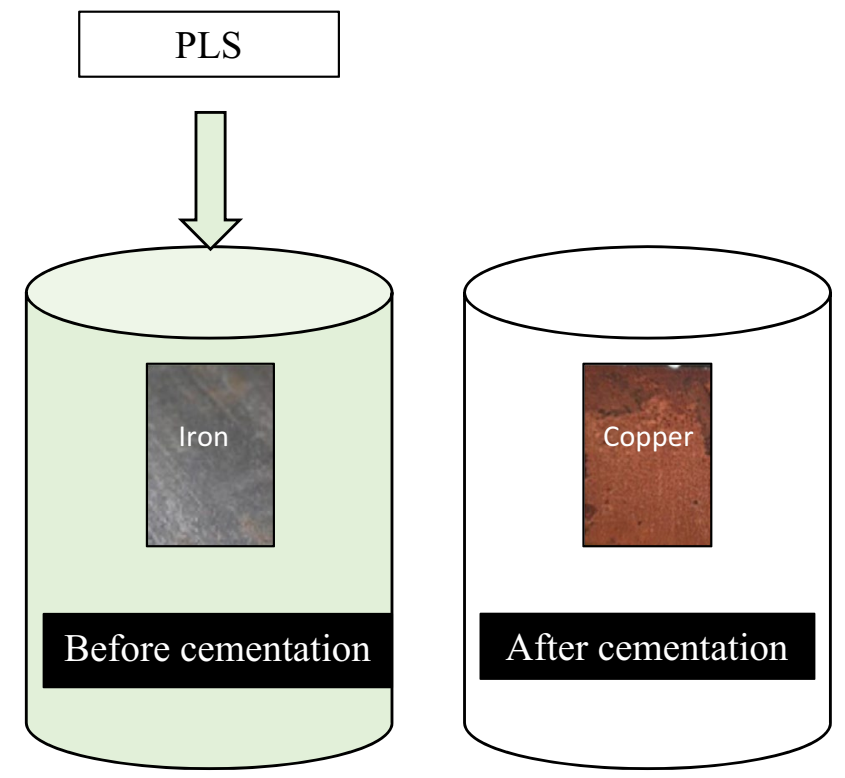

Fig. 4 The scheme of the reactor

Table 4 Levels of effective parameters for cementation testing

\begin{tabular}{llcc}
\hline Control factor & Unit & Surface & \\
\cline { 3 - 4 } & & Low level & High level \\
\hline time & Minutes & 20 & 10 \\
Concentration of copper & g/l & 7 & 3 \\
pH & - & 2 & 1 \\
Stirrer speed & RPM & 500 & 200 \\
\hline
\end{tabular}

$K=\frac{-\operatorname{Ln} \frac{C_{t}}{C_{0}}}{t}$

In this formula $C_{o}$ is the initial copper concentration, $C_{t}$ is the copper concentration after a given time and $t$, time. In the cementation experiments, reaction time, $\mathrm{pH}$, agitation rate and copper concentration were selected as effective parameters in the cementation process. Also for the experiments the factorial method was used in the design of the experiments. In these experiments, kinetics and recovery of cementation operations were considered as the process response. Selected levels of the factors are presented in Table 4. Factors values (levels) were determined based on the previous experiences.

\subsection{Selection of effective factors and their values}

\subsubsection{The effect of copper ion concentration}

Concentrations of copper ions have several different effects that in some cases work against each other. In some 
cases it increases the kinetics and in some cases it reduces the kinetics. (a) Increasing the copper concentration reduces the rate of electrochemical reaction. (b) Increasing the copper concentration results in fine grains and condensation of the copper sediment, thereby decreasing permeability and the cementation kinetics. (c) Increasing the copper concentration will precipitate more copper per unit time, which will result in a higher cathode area for subsequent sediments, thereby increasing the cementation kinetics. When the reaction rate is controlled by the chemical reaction, an increase in concentration reduces the cementation rate. However, when the kinetics of the reaction is controlled by diffusion, an increase in copper concentration increases the rate of cementation.

\subsubsection{The effect of acid concentration}

Acid concentration also has on effect on the rate and kinetics of cementation. For instance, with $\mathrm{pH}$ increasing, the reaction kinetics usually decreases. High acid concentrations contain more metal ions, which increases the recovery rate. At low $\mathrm{pHs}, \mathrm{H}^{+}$ions are high concentrated and in competing with copper cations. $\mathrm{pH}$ meter was used to measure $\mathrm{pH}$, sulfuric acid to reduce $\mathrm{pH}$ and lime was used to increase $\mathrm{pH}$. Considering that there is always a sufficient amount of iron available for the recovery of hydrogen and copper, copper is more likely to be reducted.

\subsubsection{Effect of stirring speed}

Increasing in stirring speed will increases the kinetics of copper ions transfer to the iron surface. Thereby, the kinetics of the cementation reaction increases. But once the stirring rate has exceeded a certain value, further increase will have no effect on the reaction kinetics. In addition, increasing the stirring rate has another positive effect, which separates the cemented copper from the iron surface. Thereby exposing more fresh iron to the copper solution and enhancing the reaction kinetics.

\subsubsection{Time effect}

Considering the surface oxidation of the iron sheets shortly after testing the oxidized surface of the iron dissolves in the solution this process does not lead to the reduction of copper. Therefore, in the initial time of the cementation process, the iron consumption would be high and copper recovery would be low.

\subsubsection{Design of cementation experiment}

Design-Expert software (Version 7.0, State-Ease Minneapolis, MN, USA), (DX7) software is used for designing the experiments. Factorial method was used for cementation experiments. Four central points were used in the experiment design method and 12 experiments were proposed by the software overally. The experiments designed by the software are shown in Table 5 . The variance analysis for copper recovery in the experiments is also presented in Table 6, which indicates that the proposed model is significant. The table also presented that all three parameters of time, copper concentration and stirring speed have a significant effect on copper recovery [18]. In the cementation experiments, the normal plot in Fig. 5, and the plotted predicted values and versus experiment values are shown in Fig. 5. Figure 6, shows the normal distribution of results. The predicted values for copper extraction in the cementation tests were in good correlation with the measured values.
Table 5 Design of cementation experiments

\begin{tabular}{lllllll}
\hline Run & $\begin{array}{l}\text { A: time } \\
\text { min }\end{array}$ & $\begin{array}{l}\text { B: copper } \\
\text { conc } \\
\text { g/l }\end{array}$ & C: pH & $\begin{array}{l}\text { D:agitating } \\
\text { RPM }\end{array}$ & $\begin{array}{l}\text { Cu } \\
\text { recovery } \\
\%\end{array}$ & Kinetics 1/min \\
\hline 1 & 10 & 3 & 2 & 500 & 83.01 & 0.18 \\
2 & 20 & 3 & 1 & 500 & 47.67 & 0.03 \\
3 & 20 & 7 & 2 & 500 & 59.00 & 0.04 \\
4 & 15 & 5 & 1.5 & 350 & 48.20 & 0.04 \\
5 & 15 & 5 & 1.5 & 350 & 52.00 & 0.05 \\
6 & 10 & 7 & 2 & 200 & 49.86 & 0.07 \\
7 & 10 & 7 & 1 & 500 & 85.86 & 0.20 \\
8 & 15 & 5 & 1.5 & 350 & 53.20 & 0.05 \\
9 & 20 & 3 & 2 & 200 & 67.00 & 0.06 \\
10 & 20 & 7 & 1 & 200 & 52.29 & 0.04 \\
11 & 10 & 3 & 1 & 200 & 66.67 & 0.11 \\
12 & 15 & 5 & 1.5 & 350 & 49.80 & 0.05 \\
\hline
\end{tabular}


Table 6 Analysis of variance of copper recovery

\begin{tabular}{lccccc}
\hline Source & Sum of squares & $d f$ & Mean square & F value & $p$ value prob $>F$ \\
\hline Model & 1464.75 & 5 & 292.95 & 43.06 & 0.0004 \\
A-time & 441.47 & 1 & 441.47 & 64.89 & 0.0005 \\
B-copper conc & 37.56 & 1 & 37.56 & 5.52 & 0.0656 \\
D-agitating & 197.15 & 1 & 197.15 & 28.98 & 0.0030 \\
AC & 261.22 & 1 & 261.22 & 38.39 & 0.0016 \\
AD & 527.35 & 1 & 527.35 & 77.51 & 0.0003 \\
\hline
\end{tabular}

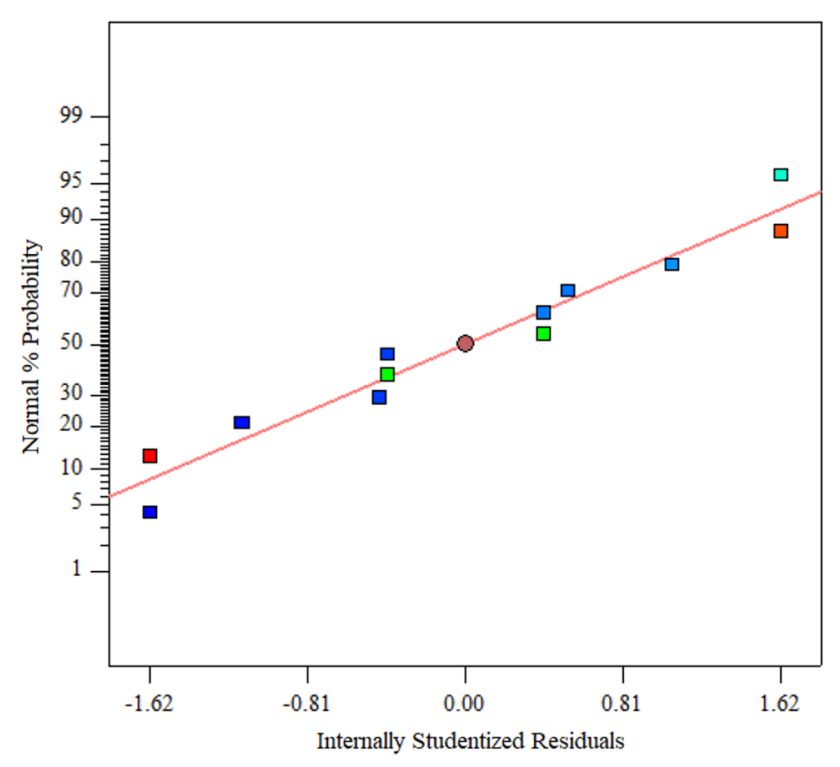

Fig. 5 Normal diagram for cementation experiments

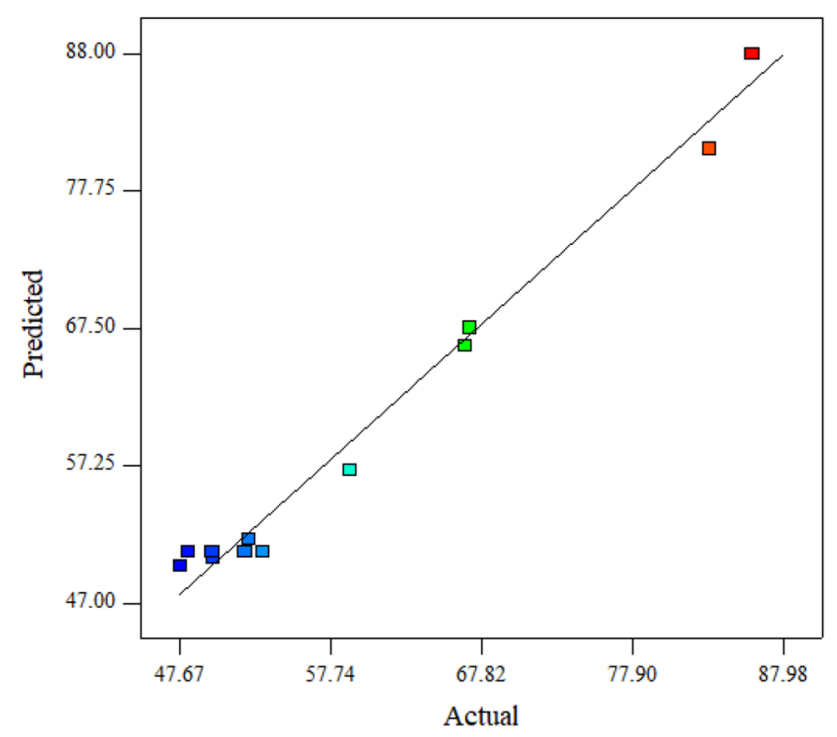

Fig. 6 Predicted results diagram versus test results for cementation experiments

\section{Results analysis}

In order to assess the effect of different parameters on copper cementation and recovery, the factors whose effects are presented in Fig. 7, are evaluated. It is observed that at low stirring velocities, copper recovery rate increases with time. At high stirring velocities, recovery rate also decreases with time. Regarding stirring speed, recovery rates increase at earlier times, but by time passing, the recovery rate decreases with increasing speed due to low available iron surface. Also, as time increases, part of the copper may be transferred back into the solution. It should be noted that the parameters of cementation interact with each other, as well as the availability of iron's surface is determinative. Therefore, analysis should be carried out with respect to this parameter. Then the interaction of the parameters and their impact on the process kinetics was investigated. The effect of time and $\mathrm{pH}$ interactions is shown in Fig. 8. It is observed that the recovery rate of cementation has increased with time. The highest recovery value was obtained at the lowest $\mathrm{pH}$ and the highest stirring speed. Figure 9, also shows the interaction of time and stirring speed on cement recovery rate. It is observed that the rate of recovery is related to changes in stirring speed and time, and with increasing stirring speed in earlier times, the maximum amount of recovery is obtained. Since the kinetics of cementation is also effective in the process, the kinetics parameters were further analyzed. At first the variance analysis table was created for the cementation kinetics parameter. Variance analysis is presented in Table 7 which shows that the proposed model is significant. In this table the effective parameters on the cementation kinetics are presented. The studies also showed that the predicted values and the values obtained from the experiment are in good correlation, which is presented in Fig. 10. The parameters affecting the cementation kinetics are presented in Fig. 11. It is observed that the kinetics constant decreases with time and this constant decreases with copper concentration increasing, which may be due to the available 


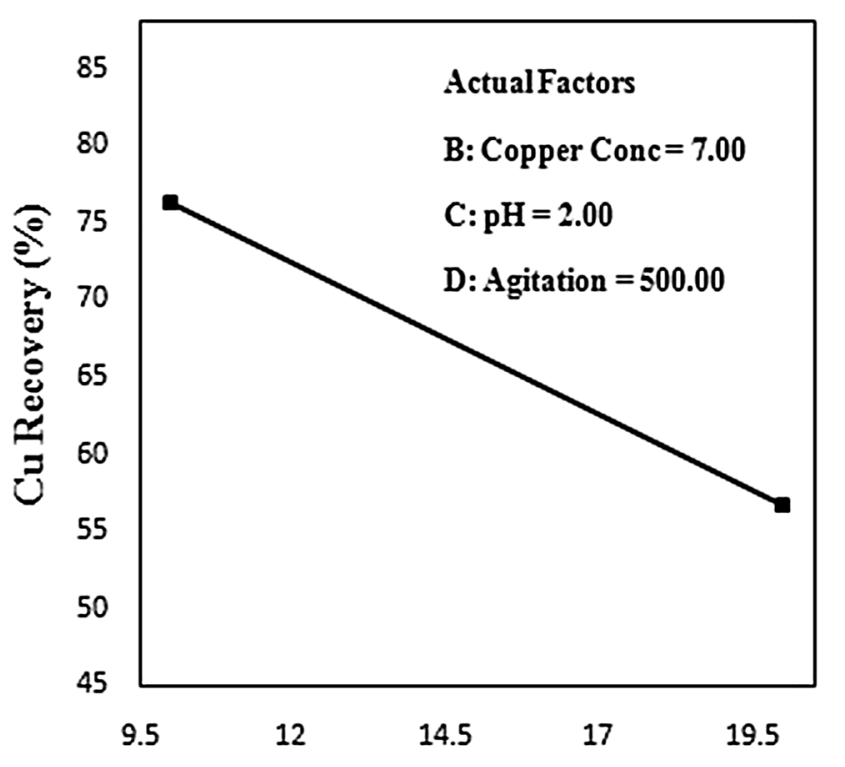

A: Time (min)

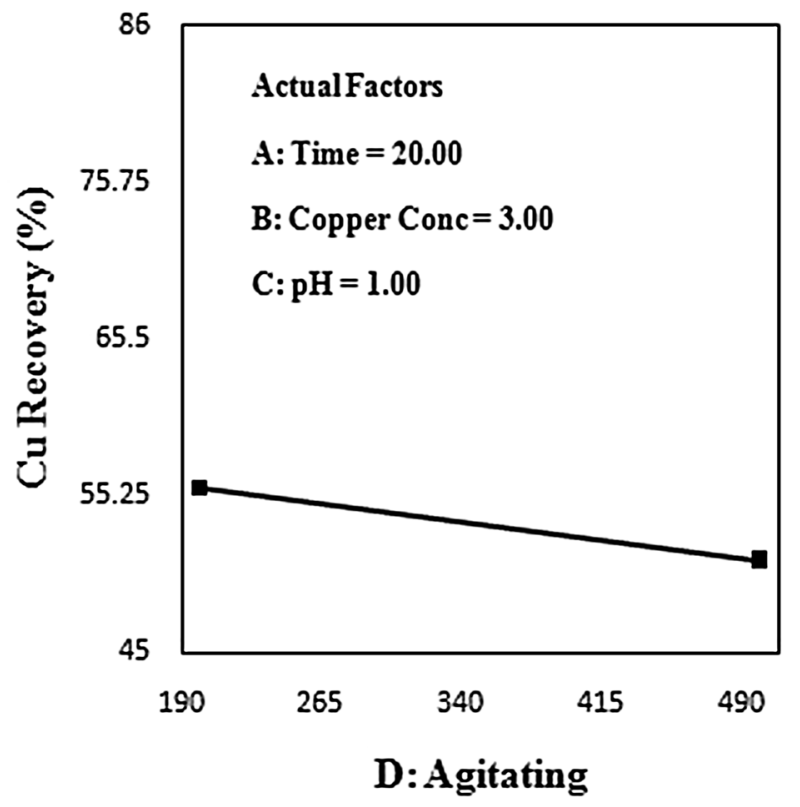

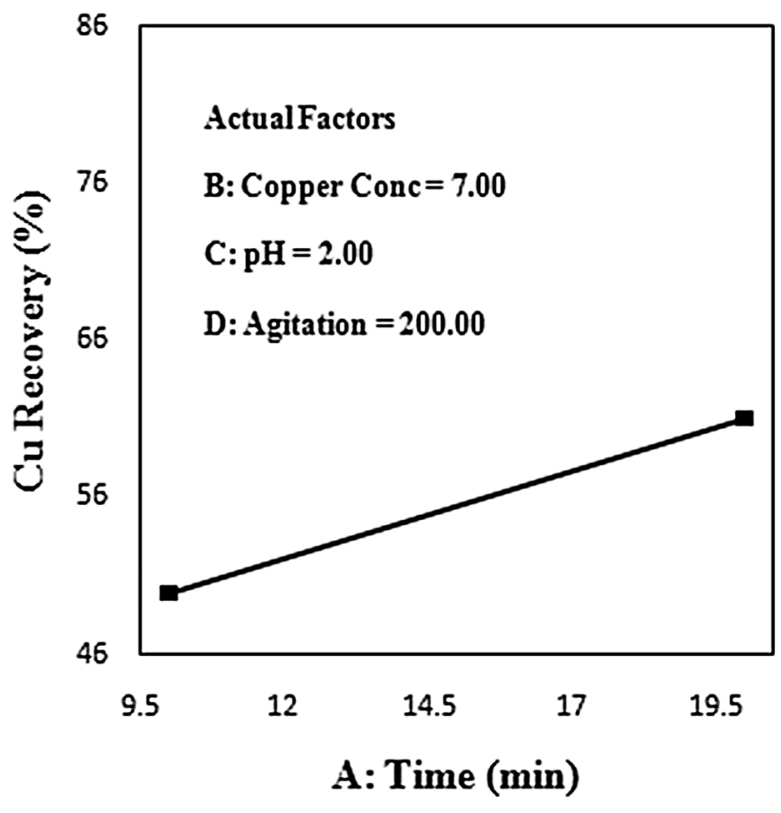

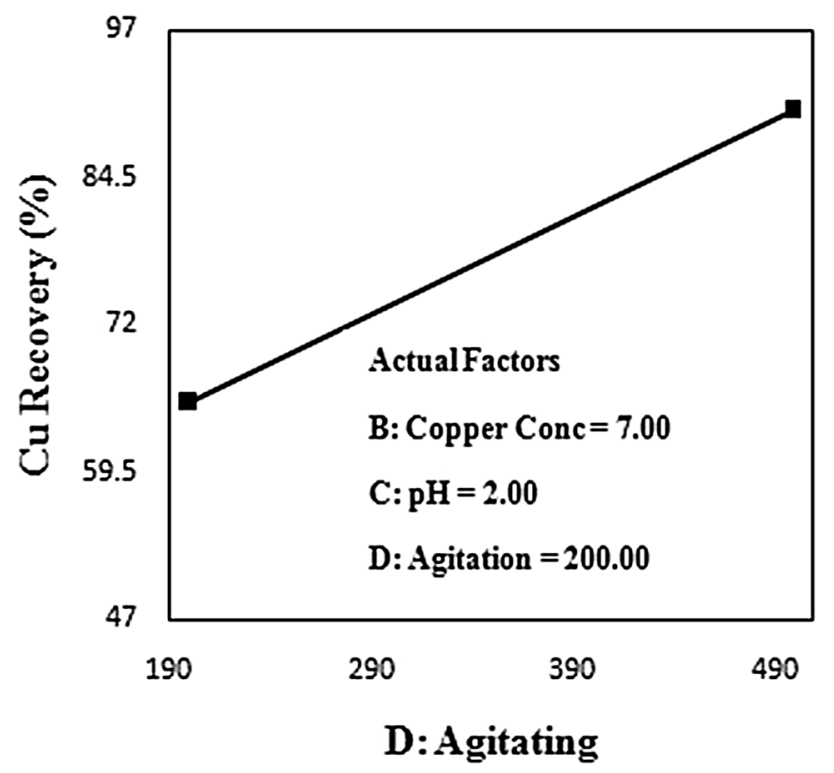

Fig. 7 Influence of different parameters on recovery of copper cementation

iron surface. The stirring speed has a great effect on the kinetics constant. Cementation kinetics increased with stirring intensity increasing. This shows that the cementation kinetics is controlled by mass transfer and diffusion. As shown in Fig. 12, the interaction of the two parameters of time and $\mathrm{pH}$ has an effect on the kinetics constant. The kinetics constant decreases with time. Also, the highest kinetics constant was obtained at the lowest time and $\mathrm{pH}$ value. In other words, $\mathrm{pH}$ decreasing and low cementation time have a positive effect on cementation kinetics constant. According to the interaction of reaction time and stirring speed which is shown in Fig. 13, it can be deduced that both parameters have an effect on the kinetics constant, but the effect of stirring speed was greater. In addition, at short reaction times (10 min), the effect of stirring speed is much greater rather than the long times. Increasing time has also led to decrease kinetics constant in the cementation reaction. In addition, at $20 \mathrm{~min}$, the effect of stirring speed on the kinetics constant is very low. Based on the results of cementation recovery and its kinetics constant, the predictive model was proposed by the software. This equation is coded based on values. The following equation can be used to predict copper recovery level values. 


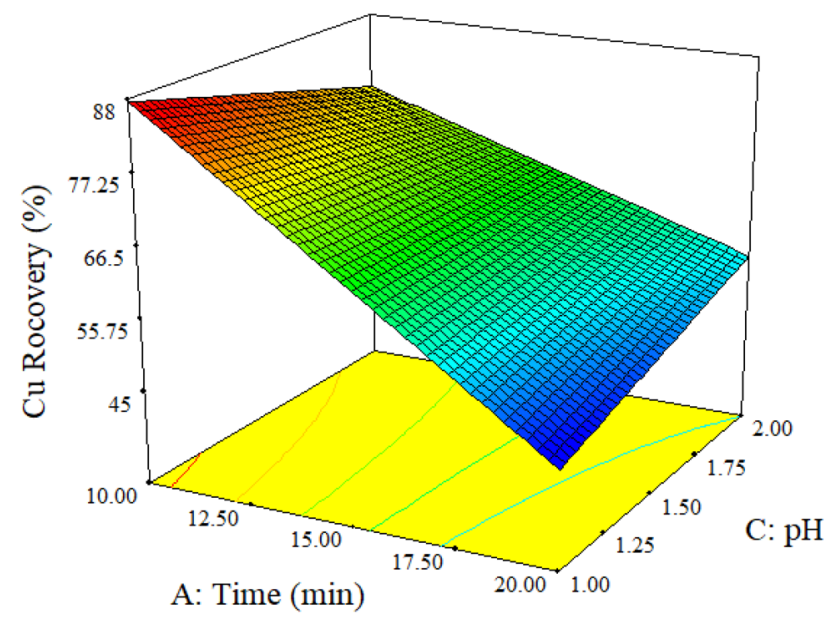

Fig. 8 The interaction effect of time and pH on cementation recovery

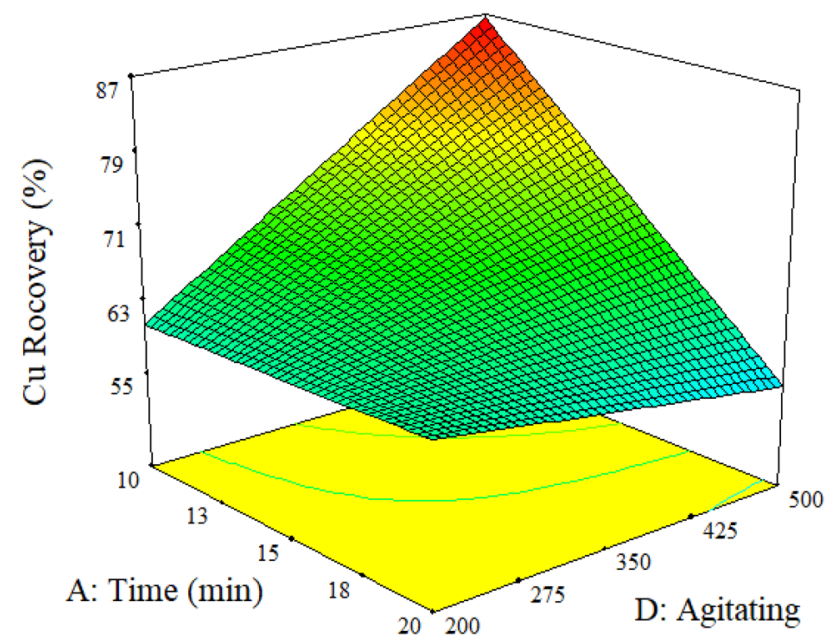

Fig. 9 The interaction effect of stirring speed and reaction time on cementation recovery

$$
\begin{aligned}
\text { Cu Rocovery }= & +63.92-7.43 \times A-2.17 \\
& \times B+4.96 \times D+5.71 \\
& \times A \times C-8.12 \times A \times D
\end{aligned}
$$

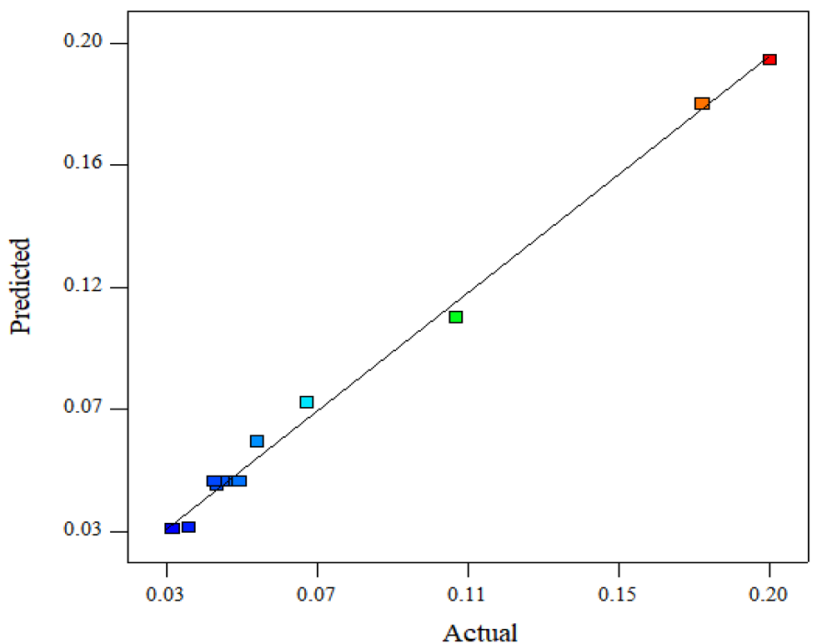

Fig. 10 Predictive results chart versus test results for cementation kinetics

The following equation can also be used to calculate the kinetics constant.

$$
\begin{aligned}
\text { Kinetics }= & +0.090-0.048 \times A-3.583 E \\
& -003 \times B+0.022 \times D+0.011 \\
& \times A \times C-0.026 \times A \times D
\end{aligned}
$$

\subsection{Validation results}

The optimal test conditions were proposed by the software. For validation, a test was performed under the specified conditions and an experiment based on previous studies near the optimum point. The results showed a good correlation between predicted and actual experiments. The validation test results are presented in Table 8.
Table 7 Analysis of variance of cementation kinetics

\begin{tabular}{llllrc}
\hline Source & Sum of squares & $d f$ & Mean square & F value & $p$ value prob $>F$ \\
\hline Model & 0.02884 & 5 & 0.005768 & 177.60 & $<0.0001$ \\
A-time & 0.018269 & 1 & 0.018269 & 562.48 & $<0.0001$ \\
B-copper conc & 0.000103 & 1 & 0.000103 & 3.16 & 0.1355 \\
D-agitating & 0.00398 & 1 & 0.00398 & 122.53 & 0.0001 \\
AC & 0.00101 & 1 & 0.00101 & 31.09 & 0.0026 \\
AD & 0.00548 & 1 & 0.00548 & 168.72 & $<0.0001$ \\
\hline
\end{tabular}



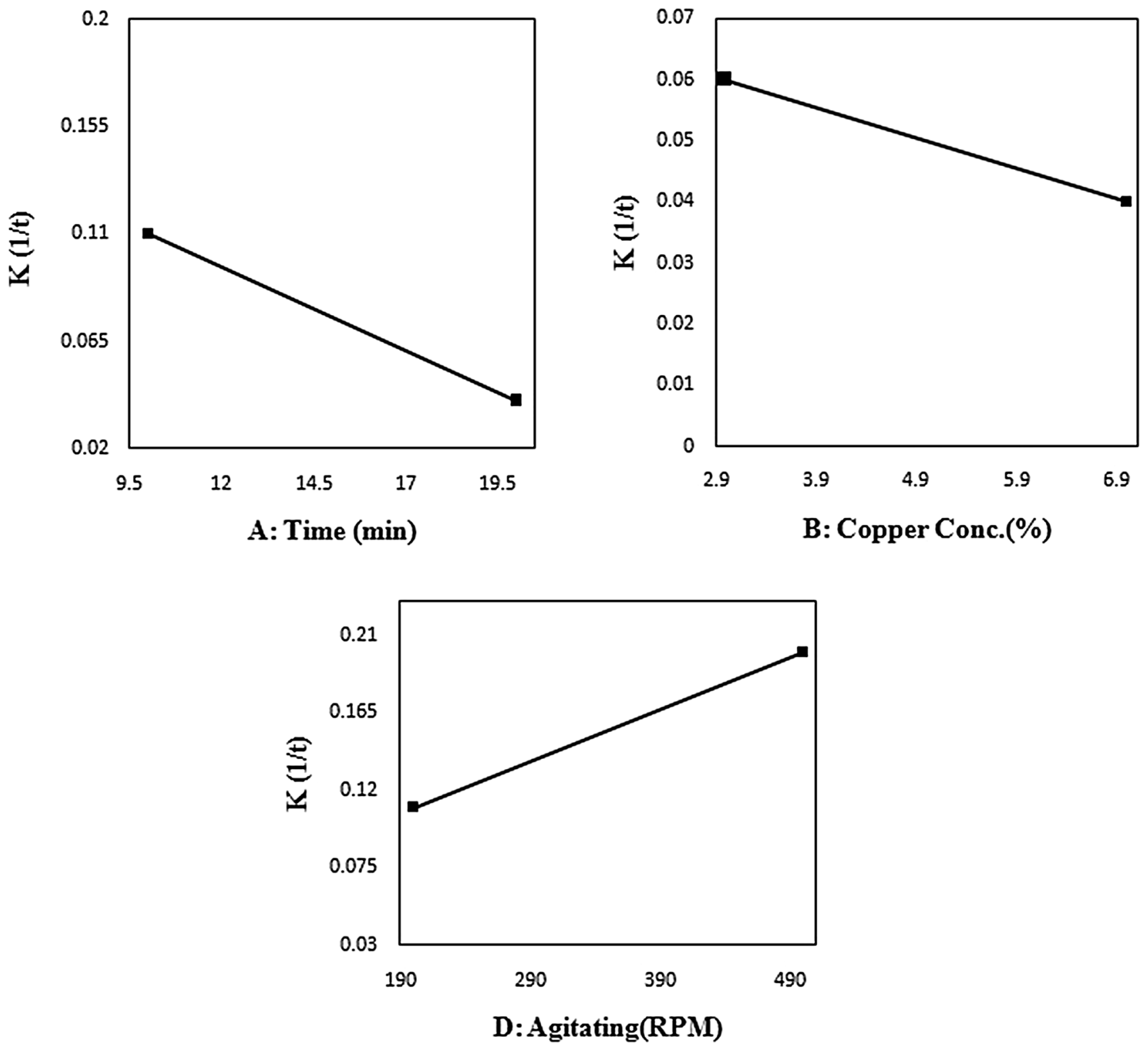

Fig. 11 The effect of different parameters on the constant of cementation kinetics

\section{Conclusions}

In this study, the extraction of cemented copper from Dogan copper mine was considered. According to the studies, the following results can be deduced: A predictive model for predicting copper recovery in cementation operations was proposed by the software, that can be used to predict copper recovery values. The grade of the sample was $1.1 \%$ and leaching test was carried out under the following conditions: acid consumption of $200 \mathrm{~kg} / \mathrm{ton}$, leaching time of $210 \mathrm{~min}$. The result was $7.3 \mathrm{~g} / \mathrm{l}$ copper and 0.41 iron at $\mathrm{pH}=0.9$. The results of the cementation experiments showed that the three parameters of time, stirring speed and concentration of copper had the most influence on the process of copper cementation. The results of the cementation kinetics analysis showed that time and stirring speed had the most effect on cementation kinetics. Also, the stirring speed-time 


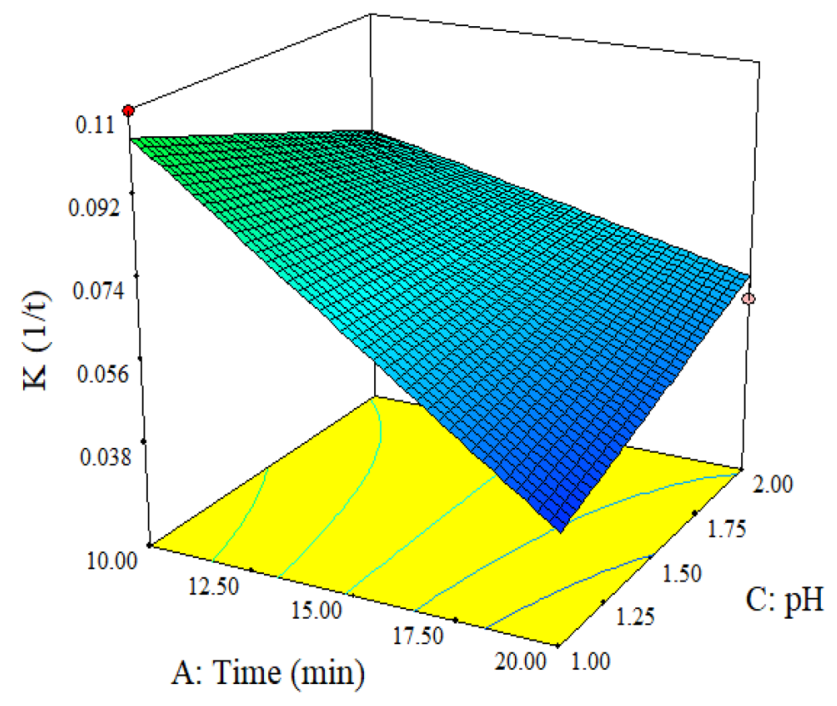

Fig. 12 The interaction effect of reaction time reaction and process $\mathrm{pH}$ on cementation kinetics constant

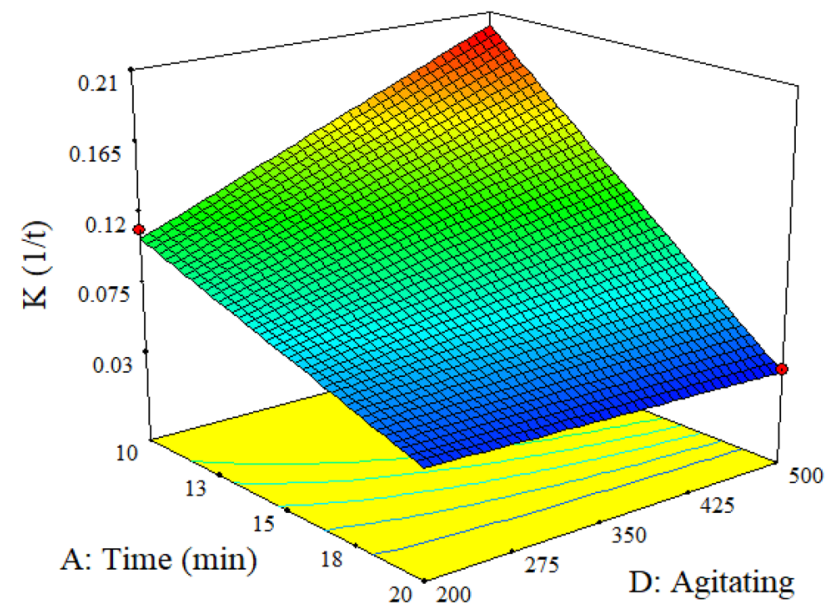

Fig. 13 The interaction effect of reaction time interaction and stirring speed on cementation kinetics constant

interaction had the greatest effect on the cementation kinetics. Finally, 10 min time, copper concentration of $3 \mathrm{~g} / \mathrm{l}, \mathrm{pH}=1$ and stirring speed of $500 \mathrm{RPM}$ were selected as optimum cementation conditions that resulted $90 \%$ of copper recovery.

\section{Compliance with ethical standards}

Conflict of interest The author(s) declare that they have no competing interests.

\section{References}

1. de Lemos LR, Santos IJB, Rodrigues GD, da Silva LHM, da Silva MCH (2012) Copper recovery from ore by liquid-liquid extraction using aqueous two-phase system. J Hazard Mater 237:209-214

2. Kiraz E (2014) Recovery of copper from oxide copper ore by flotation and leaching. Master of science thesis the Graduate School of Natural and Applied Sciences of Middle East Technical University

3. Nicol MJ (2018) The kinetics of the dissolution of malachite in acid solutions. Hydrometallurgy 177:214-217

4. Radmehr V, Koleini SMJ, Khalesi MR, Mohammadi MRT (2013) Ammonia Leaching: a new approach of copper industry in hydrometallurgical processes. J Inst Eng Ser D 94(2):95-104

5. Wei LIU, Tang MT, Tang CB, Jing HE, Yang SH, Yang JG (2010) Dissolution kinetics of low grade complex copper ore in ammonia-ammonium chloride solution. Trans Nonferrous Metals Soc China 20(5):910-917

6. Bingöl D, Canbazoğlu M (2004) Dissolution kinetics of malachite in sulphuric acid. Hydrometallurgy 72(1-2):159-165

7. Nassef E, El-Taweel YA (2015) Removal of copper from wastewater by cementation from simulated leach liquors. J Chem Eng Process Technol 6(1):1

8. Kokes H, Morcali MH, Acma E (2014) Dissolution of copper and iron from malachite ore and precipitation of copper sulfate pentahydrate by chemical process. Eng Sci Technol Int J 17(1):39-44

9. Agrawal RD, Kapoor ML (1982) Theoretical considerations on the cementation of copper with iron. J South Afr Inst Min Metall 82(4):106-111

10. Stefanowicz T, Osińska M, Napieralska-Zagozda S (1997) Copper recovery by the cementation method. Hydrometallurgy 47(1):69-90

11. Zuo C, Jagodzinski PW (2005) Surface-enhanced Raman scattering of pyridine using different metals: differences and explanation based on the selective formation of a-pyridyl on metal surfaces. J Phys Chem B 109(5):1788-1793

12. Ranjbar M, Shafiei M (2012) Optimization of operational parameters of copper cementation from base-level leaching solutions. M.Sc. in Kerman Shahid Bahonar University

Table 8 Validation test results

\begin{tabular}{llllllll}
\hline Test no. & Test type & Time $(\mathrm{min})$ & $\begin{array}{l}\text { Copper } \\
\text { conc }(\mathrm{g} / \mathrm{l})\end{array}$ & $\mathrm{pH}$ & Stirring (RPM) & Cu rocovery (\%) & $\begin{array}{l}\text { Kinetics } \\
\text { rate }(1 / \\
\text { min) }\end{array}$ \\
\hline 1 & Software & 10 & 3.08 & 1 & 496.91 & 91.95 & 0.20 \\
2 & Run & 10 & 3 & 1 & 500 & 90.33 & 0.23 \\
3 & Run & 15 & 5 & 1 & 500 & 89.8 & 0.18 \\
\hline
\end{tabular}


13. Irannegade M, Salari Rad M, Aghamohammadi M (2009) Investigate and study of copper cementation Kinetics Amirkabir Scientific Journal 20(70):63-70 (in Persian)

14. Ku Y, Chen CH (1992) Kinetic study of copper deposition on iron by cementation reaction. Sep Sci Technol 27(10):1259-1275

15. Karavasteva M (2005) Kinetics and deposit morphology of copper cementation onto zinc, iron and aluminium. Hydrometallurgy 76(1-2):149-152

16. Demirkıran N, Ekmekyapar A, Künkül A, Baysar A (2007) A kinetic study of copper cementation with zinc in aqueous solutions. Int J Miner Process 82(2):80-85

17. Gros F, Baup S, Aurousseau M (2011) Copper cementation on zinc and iron mixtures: part 2: fluidized bed configuration. Hydrometallurgy 106(1-2):119-126
18. Asghari M, Nakhaei F, VandGhorbany O (2019) Copper recovery improvement in an industrial flotation circuit: a case study of Sarcheshmeh copper mine. Energy Sources Part A Recovery Util Environ Eff 41(6):761-778

Publisher's Note Springer Nature remains neutral with regard to jurisdictional claims in published maps and institutional affiliations. 